\title{
楕円領域を持つファジィクラシファイアのロバスト化*
}

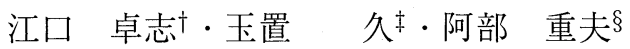

\section{A Robust Fuzzy Classifier with Ellipsoidal Regions*}

Takashi EGUCHI ${ }^{\dagger}$, Hisashi TAMAKI ${ }^{\ddagger}$ and Shigeo $\mathrm{ABE}^{\S}$

In this paper, we discuss a robust training method for a fuzzy classifier with ellipsoidal regions. First, we define a fuzzy rule for each class. Next, we determine the weight for each training datum by the two-stage method in order to suppress the effect of outliers. Then, using these weights, we calculate the center and covariance matrix of the ellipsoidal region for each class and tune the fuzzy rules. After tuning, to further improve generalization ability, we tune fuzzy rules between two classes using the training data in the class boundary. We demonstrate the effectiveness of our method using four benchmark data sets.

\section{1.はじめに}

パターン認識の総合的な性能は, 観測, 前処理, 特徵抽 出, 識別のおのおのの過程の性能の良さに依存する.識 別過程では, その前の 3 過程により数値化された特徵量 の集まりであるデー夕を扱う。教師データとして収集さ れるパターンの中には, クラスの境界があいまいで専門 家を持ってしても分類が難しいものもあり，また装置の 不調や人為的ミス, 特徵量の取り方によっては, 外れ値 が混入されている場合がある。しかしながら数值化され た高次元の特徵量の集まりであるデー夕に外れ值が含ま れているかどうかを判断することは難しい.

この外れ值の問題に対して, ニューラルネットにおいて はいくつかの手法が考えられているが $[1,2]$, 距離関数に マハラノビス距離を用いた棈円領域を持つファジィクラ シファイア $[3,4]$ では, 外れ值の影響は考慮に入れられて

* 原稿受付 2000 年 2 月 2 日

†東京電力 (株) Tokyo Electric Power Company; 1-1-3 Uchisawai-cho 1-Chome, Chiyoda-ku Tokyo, 100-0011, JAPAN

‡神戸大学 工学部 情報知能工学科 Department of Computer and Systems Engineering, Kobe University; Rokkodai, Nada, Kobe, 657-8501, JAPAN

$\S$ 神戸大学 大学院 自然科学研究科 Graduate School of Science and Technology, Kobe University; Rokkodai, Nada, Kobe, 657-8501, JAPAN

Key Words: pattern recognition, fuzzy classifiers, robustness, outliers.
いない。このマハラノビス距離に対して外れ值の影響を 考慮に入れた統計分野における一つの手法として Stahel とDonohoの方法 [5] がある.この方法では, おのおのの デー夕の中央值からの離れ具合いを求め, 離れ具合を単 調減少関数により重みに変換して，おのおののデータを 重み付けして, 中心と共分散行列を求める。この方法は, 外れ值を含む場合は有効であるが，外れ值を含まないと きには，外れ值でないデー夕の重みを小さくして，中心 と共分散行列の計算に影響を及ぼす可能性がある.

$$
\text { パターン認識のシステムを開発する際に,データの中 }
$$
に外れ值が含まれるかどうかはあらかじめ分からないか ら，外れ值が含まれないときも汎化能力の低下しない方 式を開発する必要がある。このため本論文では, 棈円領 域を持つファジィクラシファイアが外れ值のありなしに かかわらず高い汎化能力を実現できるように, Stahel と Donohoの方法の拡張を図るとともに, 汎化能力を向上す るためのパラメータのチューニング法を提案する.すなわ ち，まず最初にStahel とDonohoの方法によりクラスに 含まれるデー夕の重みを決めて中心と共分散行列を求め, それに基づき識別してクラス境界付近のデー夕を求める. つぎに境界付近のデータによりクラスごとにしきい值を 求め, それを境に減少関数でデー夕に重み付けをするこ とにより中心と共分散行列への外れ值の影響を抑える 2 段階の学習を行う.さらに従来の楕円領域を持つファジィ 
クラシファイアのファジィルールのチューニングでは, 外 れ值が含まれない場合にはよい認識率を得られるが外れ 値を含んだ教師データにより学習をすると影響が出てく る.そこで外れ値の影響を抑えるために，新たに外れ值 を考慮にいれてクラス間のチューニングを行う。これに より，教師データに外れ值を含んだデータがある場合に も, また含んでいない場合にも汎化能力の高い学習がで きることを示す.

以下，2. で参考文献 $[3,4]$ に基づいて棈円領域を持つ ファジィクラシファイアについて述べた後， 3. でロバス トな学習方式について詳述する.さらに 4. でロバストな 学習方式の効果をいくつかのベンチマークデータで評価 する。

\section{2. 楕円領域を持つファジィクラシファイァ によるパターン認識}

マハラノビス距離をベースにした楕円領域を持つファ ジィクラシファイアでは, クラスタごとにマハラノビス距 離を調整するチューニングパラメー夕を導入し, これを教 師データの認識率が最大になるように調整する。すなわ ちある一つのチューニングパラメータを変えたときに， 正しく認識されていた教師データが誤認識する点, およ び誤認識していたデータが正しく認識される点のチュー ニングパラメータの值を求め, これにより, 教師デー夕 の認識率が最大になる值にチューニングパラメータを調 整する．さらにこれをすべてのチューニングパラメータ について, 教師データの認識率の向上がなくなるまで繰 り返す。このように認識率を直接的に最大化するために， 認識率に対応する微分可能な目的関数を最適化する従来 の学習法に比べてきわめて高速に学習できるという特徵 がある。

参考文献 [4] では最初に各クラスに一つのファジィルー ルを定義して, 必要に応じてルールを定義する方法を述 べているが, 通常の場合一つのクラスに一つのルールを 定義するので十分であるために，以下では各クラスに一 つのファジイルールを定義する場合について述べる.

特徴量の集まりであるパターンベクトル $\mathrm{x}$ をもつ入力 を $n$ 個のクラスに分類することを考える。はじめにおの おののクラス $i$ にぎのファジィルールを定義する.

$$
R_{i}: \text { If } \mathbf{x} \text { is } \mathbf{c}_{i} \text { then } \mathbf{x} \text { is class } i
$$

ここで， $\mathbf{c}_{i}$ はクラス $i$ の中を意味し，クラス $i$ に属す 教師データにより次式で計算する.

$$
\mathbf{c}_{i}=\frac{1}{N_{i}} \sum_{\mathbf{x} \in \operatorname{class} i} \mathbf{x}
$$

ここで, $N_{i}$ はクラス $i$ に属す教師データの数である.つ ぎにいずれのクラスに属すかの程度, すなわち成立度を 示すメンバーシップ関数として $m_{i}(\mathbf{x})$ をつぎのように定 義する.

$$
\begin{aligned}
& m_{i}(\mathbf{x})=\exp \left(-h_{i}^{2}(\mathbf{x})\right) \\
& h_{i}^{2}(\mathbf{x})=\frac{d_{i}^{2}(\mathbf{x})}{\alpha_{i}} \\
& d_{i}^{2}(\mathbf{x})=\left(\mathbf{x}-\mathbf{c}_{i}\right)^{\mathrm{t}} Q_{i}^{-1}\left(\mathbf{x}-\mathbf{c}_{i}\right)
\end{aligned}
$$

ただし $, h_{i}(\mathbf{x}):$ チューニングされた距離, $d_{i}^{2}(\mathbf{x}): \mathbf{x}$ と $\mathbf{c}_{i}$ との二乗マハラノビス距離, $\alpha_{i}$ : クラス $i$ のューニ ングパラメータ, $Q_{i}:$ クラス $i$ 共分散行列である. 共 分散行列 $Q_{i}$ はつぎのように計算する.

$$
Q_{i}=\frac{1}{N_{i}} \sum_{\mathbf{x} \in \operatorname{class} i}\left(\mathbf{x}-\mathbf{c}_{i}\right)\left(\mathbf{x}-\mathbf{c}_{i}\right)^{\mathrm{t}}
$$

つぎにファジィルールをチューニングすることにより認 識率の向上を図る。ここでチューニングは， $\alpha_{i}$ をチュー ニングすることによりメンバーシップ関数の傾きだけを 行うこととする.あるクラスタに属すファジィルールの メンバーシップ関数の傾きを減少すると, そのクラス夕 のメンバーシップ関数の成立度が増加する。これにより， 傾きを減少する前では間違って分類されていたデータの 中で, 正しく分類されるデー夕が生じ, また正しく分類 されていたデータで, 間違って分類されるデータが生じ る.これにもとづいて, 正しく分類されるデータの増加 数を計算する. 同様に, 傾きを増加する場合にもそれに よって正しく分類されるデータの増加数を計算する。そ れから，認識率が最大になるように傾きを修正する。こ こでのチューニング方法は, チューニング前では正しく 分類されていたデータが, 間違って分類されることにな るとしても認識率が上がるならばそれを許してチューニ ングを行う。このような方法により，連続的にすべての ファジィルールのチューニングを行う。これは学習デー夕 の認識率の改善がなくなるまで反復して行う.

これにより実際に識別法は, あるデータの入力 $\mathrm{x} に$ に対 して,すべてのクラスについてメンバーシップ関数を計 算して, もし $m_{k}(\mathbf{x})$ が最も大きな值を示したらそのデー 夕はクラス $k$ に属するとする。(3) 式からもわかるよう にメンバーシップ関数は, 指数関数の逆数なので $[0,1]$ の 値をとる。

\section{3. ロバスト化}

2. で述べたマハラノビス距離により識別する方法では, 距離推定に用いる中心と共分散行列を (2), (6) 式を用い てクラスごとに一度計算されるとそのまま使われること になる．ここで外れ值を含む教師データにより中心と共 
分散行列を計算すると, チューニングパラメータ $\alpha_{i}$ によ りある程度の認識率の改善が行われるものの初期のクラ スの分布形状のズレにより $\alpha_{i}$ を修正後の最適性が保証 されない. しかしながら, デー夕の入力が多次元になっ てくると外れ值を含んだデータであるのかクラスの分離 に有用なデータなのか見つけることは一般に難しい.

そこでクラスの分布形状のズレを抑えるために，二段 階の学習によりクラスの分布を求め,さらに新たに 2 ク ラス間だけのルールのチューニングを行うロバストな学 習法を提案する。すなわち二段階学習の第一段階におい て, Stahel と Donoho の方法を用いて, 各教師データ に対して, 教師データに属するクラスの分布からの離れ の程度を計算し, 教師データをこの離れの程度により減 少関数で重み付けし, 中心と共分散行列を求める. 第二 段階でこれを用いマハラノビス距離により一度認識分類 する。この過程でクラス境界付近にあるデータを求める. そのデータによりクラスごとにしきい值を求め, このし きい值を用い重み付けし中心と共分散行列を求め, マハ ラノビス距離に用いる.

また従来の楕円領域を持つファジィクラシファイアの ファジィルールのチューニングでは, 外れ值が含まれな い場合には良い認識率を得られるが外れ值を含んだ教師 データにより学習をすると影響が出てくる，そこで外れ 值の影響を抑えるために，新たに外れ值を考慮にいれて 2 クラス間のチューニングを行う.

\section{1 第一段階}

おのおのの教師データの $m$ 次元パターンベクトル $\mathbf{x}_{k}(\epsilon$ class $i, i=1, \cdots, n)$ について, クラス内での離れの程度 $u_{k}$ を次式により求める.

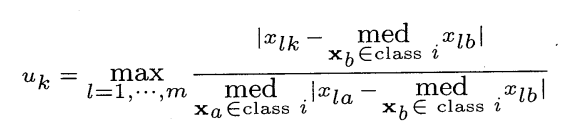

ここで, $x_{l k}$ は $\mathbf{x}_{k}$ の $l$ 番目の要素である $\operatorname{med}_{\mathbf{x}_{b} \in \text { class } i} x_{l b}$ はクラス $i$ の $l$ 番目の要素の中央值 (メディアン) を示す. この式の分子は $x_{l k}$ がクラス $i$ に属するデータの $k$ 番目 の要素の中央值からのずれを示し, 分母は分子のずれを すべてのクラス $i$ に属するデータについて求めたずれの 中央值である。したがって，分子を分母で割ることによ り， $x_{l k}$ の中央值からのずれを正規化していることにな る.さらに各次元の正規化されたずれの最大值をとるこ とにより, 特徴量の中で最も突出している部分の程度を $\mathbf{x}_{k}$ の離れの程度として計算している.

つぎに, 単調減少関数によりつぎのようにデー夕に対 して重み付けを行う。

$$
w_{k}^{(1)}\left(u_{k}\right)=\frac{1}{1+u_{k}}
$$

これらの重みを教師データについて計算し, 暫定的な中 心および共分散行列をつぎのようにして求める.

$$
\begin{aligned}
\mathbf{c}_{i}^{(1)}= & \frac{\sum_{j=1}^{N_{i}} w_{j}^{(1)}\left(u_{j}\right) \mathbf{x}_{j}}{\sum_{j=1}^{N_{i}} w_{j}^{(1)}\left(u_{j}\right)} \\
Q_{i}^{(1)}= & \frac{\sum_{j=1}^{N_{i}} w_{j}^{(1)}\left(u_{j}\right)\left(\mathbf{x}_{j}-\mathbf{c}_{i}^{(1)}\right)\left(\mathbf{x}_{j}-\mathbf{c}_{i}^{(1)}\right)^{t}}{\sum_{j=1}^{N_{i}} w_{j}^{(1)}\left(u_{j}\right)}
\end{aligned}
$$

ここで， $N_{i}$ はクラス $i$ に属すデータの個数である.

\section{2 第 2 段階}

上記で求めた暫定的な中心と共分散行列を用いてルー ルのチューニングは行わず $\left(\alpha_{i}=1.0\right)$, マハラノビス距離 のみを用い教師データを認識し, クラスの境界付近にあ るデー夕を求める。まず，ある教師データ $\mathbf{x}_{k}$ がクラス $i$ に属しているとする．つぎのような条件を満たすデー夕 を境界付近にあるデータと位置付ける。

$$
\gamma_{k}=\frac{D(2)_{k}-D(1)_{k}}{D(1)_{k}}
$$

ここで $D(1)_{k}$ はデー夕 $\mathbf{x}_{k}$ に対して各クラスのマハラノ ビス距離を計算したときの最小距離であり， $D(2)_{k}$ は 2 番目に小さい距離の值である.

境界付近にあるデータの集合を $X_{i}$ としたときに, $\gamma_{k} \leq$

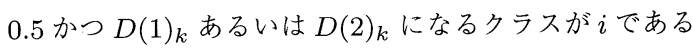
データをその集合の要素と定義する。つまりある教師デー タがクラス $i$ に属していて識別においてすべてのクラス について中心からのマハラノビス距離を求めたとき最も 近いクラスがクラス $i$ であるかしくは 2 番目に近いク ラスがiであり，かつその 2 クラスのマハラノビス距離 が接近しているデー夕を境界付近のデータとしている.

距離関数を用いた認識において境界付近のデータは大 切で距離関数のパラメー夕にあたえる影響も大きい.ま たチューニングの際にはこれら境界付近のデータが最も 重要なので重みを 1 としパラメータを計算する。そこで これらのデータから，各クラスについて境界付近にある と位置付けられたデー夕の中で $u_{k}$ の最大值をそのクラ スのしきい值とする.すなわち 


$$
\varepsilon_{i}=\max _{X_{i} \in \mathbf{x}_{k}} u_{k}
$$

そしてデータごとに重みを再分配する.

$$
w_{k}^{(2)}\left(u_{k}\right)=\left\{\begin{array}{cc}
1 & u_{k} \leq \varepsilon_{i} \\
\frac{1}{1+u_{k}-\varepsilon_{i}} & \text { otherwise }
\end{array}\right.
$$

この重みを用いて先ほどと同様に重み付けを行い, 中心 と共分散行列を求める.

$$
\begin{gathered}
\mathbf{c}_{i}^{(2)}=\frac{\sum_{j=1}^{N_{i}} w_{j}^{(2)}\left(u_{j}\right) \mathbf{x}_{j}}{\sum_{j=1}^{N_{i}} w_{j}^{(2)}\left(u_{j}\right)} \\
Q_{i}^{(2)}=\frac{\sum_{j=1}^{N_{i}} w_{j}^{(2)}\left(u_{j}\right)\left(\mathbf{x}_{j}-\mathbf{c}_{i}^{(2)}\right)\left(\mathbf{x}_{j}-\mathbf{c}_{i}^{(2)}\right)^{t}}{\sum_{j=1}^{N_{i}} w_{j}^{(2)}\left(u_{j}\right)}
\end{gathered}
$$

ここで， $N_{i}$ はクラス $i$ に属すデー夕の個数である。ま た，離散值 $(0,1)$ の特徵量に関しては，0あるいは 1 に大 きく片寄っている場合には, つぎの方法で中心を求める ものとする.

$$
c_{l i}^{(2)}=\operatorname{med}_{\mathbf{x}_{a} \in \text { class }} i_{l k}
$$

この中心 $\mathbf{c}_{i}^{(2)}$ と共分散行列 $Q_{i}^{(2)}$ を用いファジィルール $\left(\alpha_{i}\right)$ のチューニングを行い学習するものとする.

\section{3 クラス間チューニング}

ここではクラス間チューニングの方法について記述す る. $\alpha_{i}$ のチューニング [3] と異なるのは, $\alpha_{i}$ のチューニン グがすべてのクラスに対して最大の認識率が得られるよ うにチューニングを行うのに対して, クラス間のチュー ニングは $\alpha_{i}$ が認識率の向上がなくなるまでチューニング した後， 2 クラス間について 2 クラス間のデー夕のみを 用いてチューニングをすることである．またその際に用 いるデータを制限することによって外れ值を含むデー夕 によるチューニングへの影響を抑える。

$\alpha_{i}$ のチューニングの際には, 外れ值を考慮に入れてい ないので影響が出る恐れがある。またすべてのクラスに 対して最大の認識率が得られるようにチューニングを行 うため, クラス数が多くクラス間の相関が強い場合には クラス間に対して別にチューニングをするほうが最大の 認識率が得られると考えられる。そこでクラス間チュー ニングパラメータ $\beta_{i j}$ をつぎのように定義する.

$$
h_{i}^{2}(\mathbf{x})=\frac{d_{i}^{2}(\mathbf{x})}{\alpha_{i}+\beta_{i j}}
$$

実際未知デー夕を認識する際にはつぎのように行う. 従来の $\alpha_{i}$ を用いて認識を行った後, (11) 式を計算し $\gamma_{k} \leq 0.5$ を満たすデータに対しては距離を再計算する. $D(1)_{k}, D(2)_{k}$ のクラスが $i, j(i<j)$ のときクラス $i$ に対 して (17) 式により再距離計算をする。これを (3) 式によ りメンバーシップを計算することにより新たに認識分類 する.

$$
\beta_{i j} \text { のチューニング方法を以下に述べる. }
$$

ある 2 クラス間 $i, j(i<j)$ をチューニングすることを考 える，パラメータ $\alpha_{i}$ をチューニングした後, 識別を行い (11) 式を計算しつぎの条件を満たすデータによりチュー ニングを行う. すなわち， $\gamma_{k} \leq 0.5$ になる教師データのう ち教師データの属するクラスが $i$ あるいは $j$ であるデー

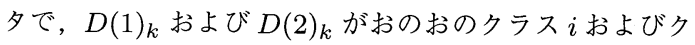
ラス $j$ かクラス $j$ およびクラス $i$ となるデー夕である.

ここで $U_{i j}(l), L_{i j}(l)$ を $l-1$ 個の正しく認識された データが䛊認識する上限および下限とする。たとえば, $\beta_{i j}$ の值を $\left[L_{i j}(2), L_{i j}(1)\right]$ の区間内の值に設定すると正 しく認識されていたデータの一つが誤認識を起こす. $\beta_{i j}$ を増加あるいは減少させると正しく認識されていたデー 夕が誤認識されることもあれば誤認識されていたデータ が正しく認識される可能性もある。 そこで $\delta_{i j}(l) を ~ U_{i j}(l)$ より小さく，以前に誤認識されていたデー夕を正しく認 識させる $\beta_{i j}$ の上限としさらに $\theta_{i j}(l)$ を $L_{i j}(l)$ より大き く, 以前誤認識されていたデー夕を正しく認識させる $\beta_{i j}$ の下限とする。

つぎに $\left(L_{i j}(l), \theta_{i j}(l)\right)$ と $\left(\delta_{i j}(l), U_{i j}(l)\right)(l=1, \cdots)$ の区 間の中でどの区間に $\beta_{i j}$ を設定すると認識率が最大にな るか調べる．最大になる区間の中央值を $\beta_{i j}$ とする．こ れをすべての 2 クラス間においてチューニングを行う.

Fig. 1は， $\beta_{i j}$ をどこにチューニングするか決定する 概念図である. ○は， $\beta_{i j}$ をチューニングする前ではクラ ス $j$ に正しく認識されていたデータであり $\beta_{i j}$ をチュー ニングすることにより誤認識される限界值をそれぞれ示 す. $\square$ ，同様にクラス $i$ に正しく認識されていたデー タでありクラス $j$ に誤認識される限界值を示す。は, チューニングする前ではクラス $j$ に誤認識されているク ラス $i$ のデータであるが，その数直線上でそれ以上に $\beta_{i j}$ をチューニングすることにより正しく認識されるデータ である. ○は同様に $\beta_{i j}$ をそれ以下にチューニングする とクラス $j$ に正しく認識されるデータである. Fig. 1の ように $\beta_{i j}$ をチューニングすると, 正しく認識されてい たデータ一つが誤認識されるが誤認識されていた四つの 
$\square \quad$ Correctly classified class $i$ data

Misclassified class $i$ data

Correctly classified class $j$ data

- Misclassified class $j$ data

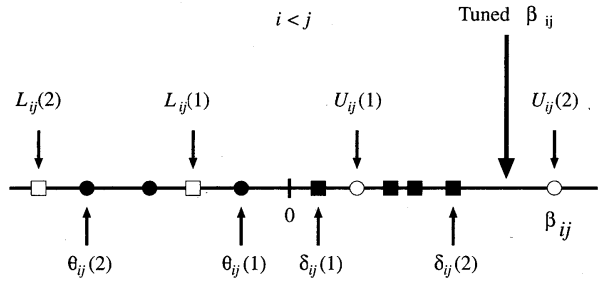

Fig. 1 Determination of tuned $\beta_{i j}$. If $\beta_{i j}$ is modified to the tuned $\beta_{i j}$, misclassified three data are correctly classified.

データが正しく認識されることになる。このように，認 識率が改善されるときは正しく認識されていたデータが 誤認識されることを許して最適な $\beta_{i j}$ の修正量を決める. このようにしてすべての 2 クラス間について $\beta_{i j}$ をチュー ニングする

\section{4. シミュレーションによる評価}

ここでは，血球デー夕 [6]，ひらがなデー夕，サイロイ ドデー夕 [7], そして数字データ $[8,9]$ で教師データに外 れ值を含まない場合にも提案する手法が最適に学習でき ることを示すとともに, 血球およびひらがなデー夕の教 師デー夕に外れ值を含んだデー夕を混入し，これを用い て学習を行った場合にもテストデータに対する高い認識 率を得られることを示す.

血球デー夕は，3097 個の学習デー夕と 3100 個のテス トデータからなる。血球の分類とは白血球を核の周囲長, 面積などの 13 個の特徵量から 12 のクラスに分類するも のである.クラスは血球の成長の段階にしたがって定義 されているので，隣接したクラスの境界があいまいで専 門家を持ってしても分類は難しいものである.

ひらがなデー夕は，車のナンバープレートの文字を認 識するために集められたデータである.8375 個の学習 データと 8356 個のテストデータからなり，13 の特徴量 から 38 のクラスに分類する。

数字データは, 車のナンバープレートの数字を認識す るために集められたデータである。道路を走行する車を カメラでとり，おのおのの数字に対して 12 個の特徵量か ら 10 のクラスに分類するデータで，810個の学習データ と 820 個のテストデータよりなる.

サイロイドデータは，21個の特徴量から 3 のクラスに 分類するものである. 学習デー夕は 3772 個でテストデー 夕は 3428 個からなる. サイロイドデータは 15 の入力が 0, 1 の離散值で, $92 \%$ 以上のデータが一つのクラスに属
している

Table 1 はそれぞれのデー夕の特徵をまとめたもので ある。

Table 1 Feature of benchmark data

\begin{tabular}{|c|c|c|c|c|}
\hline Data & Inputs & Classes & Train. & Test \\
\hline Blood cell & 13 & 12 & 3097 & 3100 \\
Hiragana & 13 & 38 & 8375 & 8356 \\
Numeral & 12 & 10 & 810 & 820 \\
Thyroid & 21 & 3 & 3772 & 3428 \\
\hline
\end{tabular}

\section{1 外れ值を含む学習データの作成}

外れ值を含んでいない教師データよりランダムにデー 夕を選び，そのデータのいくつかの特徵量をまたランダ ムに選び，属すクラスに対して外れ值となるようにデー 夕を作成する．外れ值は，特徵量の分布の中心から通常 の 2 倍から 3 倍の数值になるように設定する．特徴量は 連続值であり $[0,1]$ の範囲に収まるように処理を行う。

\section{2 認識例}

提案手法は，教師デー夕に外れ值を含んだデータが混 入されている場合にも最適に学習できるが，それを示す 前に教師データに外れ值を含んでいない場合にも外れ值 を考慮にいれていない従来方法と同程度あるいはそれ以 上の認識率が得られることを示す，比較のため，四つの 手法を比べる。手法 1 は，外れ值を考慮にいれていな い従来の楕円領域を持つファジィクラシファイアすなわ ち (2)，(6) 式により中心と共分散行列を計算する方法と する. 手法 2 は, 統計分野における従来の 1 手法であ る (7) 式により離れの程度を計算し減少関数を用いて (8) 式により重み付けを行い (9), (10) 式により中心と共分散 行列を計算する方法とする.

手法 3 は，二つの段階を踏み (13) 式により重み付け し (14)，(15) 式により中心と共分散行列を計算する方法 とする. 最後に手法 4 として提案手法である二つの段 階を踏みパラメー夕を求めた後，クラス間チューニング も施した方法である。

Table 2 は, 外れ值を含んでいない, 教師データで学 習を行いそれをテストデータで評価した結果を示したも のである。ここで () 内は教師デー夕の認識率を示す.

Table 2 Comparison of recognition rate for the benchmark data without outlier

\begin{tabular}{|c|c|c|c|c|}
\hline Data & Method 1 & Method 2 & Method 3 & Method 4 \\
\hline Blood & 91.65 & 89.32 & 91.29 & 91.84 \\
cell & $(95.41)$ & $(94.38)$ & $(95.38)$ & $(95.61)$ \\
\hline Hiragana & 98.79 & 98.76 & 98.80 & 98.80 \\
& $(99.99)$ & $(99.99)$ & $(99.99)$ & $(99.99)$ \\
\hline Thyroid & 95.60 & 96.62 & 96.56 & 96.73 \\
& $(96.02)$ & $(97.38)$ & $(97.11)$ & $(97.22)$ \\
\hline Numeral & 99.39 & 99.51 & 99.51 & 99.51 \\
& $(99.75)$ & $(99.75)$ & $(99.88)$ & $(99.88)$ \\
\hline
\end{tabular}


Table 2 より統計分野の手法をそのまま適用した手法 2 に比べて 2 段階の手順を踏む手法 3 の方が良い認識率 を示している。提案手法である手法 4 は, 学習デー夕に 外れ值を含んでいない場合にも従来手法である手法 1 と 比べて同程度あるいはそれ以上の認識率を得られている ことがわかる.クラス間のチューニングは手法 3 と手法 4 を比べると認識の難しい血球データで向上しているこ とがわかる。

つぎに参考文献 [4]において動的にクラスタを追加す る方法に対してサイロイドデータを用いて手法 1 と手法 4 を比較する.

簡単に動的にクラスタを追加する方法を説明すると， 本論文の説明では, 一つのクラスに対し一つの領域を割 り当てていたが，動的に追加する方法は， $\alpha_{i}$ のチューニ ング方法により認識率が改善されなくなるまでチューニ ングをした後，もし一つのクラスについて $N_{c}$ 以上他の クラスに誤認識されているデータが存在するならこの誤 認識されたデータにより新しく一つクラスタを追加する。 そして新しく追加されたタラスタについて，中心と共分 散行列を計算しファジィルールを定義する．追加したク ラスタも含めてチューニングを認識率が改善されなくな るまで行う. 再び $N_{c}$ 以上一つのクラスについて䛊認識 されたデー夕があるか計算し，あればクラス夕を追加す るアルゴリズムを繰り返し，ない場合はそこでクラスタ を追加するアルゴリズムを終了する。

Table 3 は， $N_{c}$ を変化させたときの手法 1 と手法 4 に ついて比較した結果を示す.

Table 3 Performance for the thyroid data by changing $N_{c}$

\begin{tabular}{|c|cc|cc|}
\hline$N_{c}$ & Method 1 & Rules & Method 4 & Rules \\
\hline- & $95.60(96.02)$ & 3 & $96.73(97.22)$ & 3 \\
40 & $97.00(98.12)$ & 5 & $96.91(97.51)$ & 4 \\
30 & $97.26(98.44)$ & 8 & $97.49(98.67)$ & 6 \\
20 & $97.17(98.67)$ & 10 & $97.72(98.75)$ & 6 \\
10 & $97.29(99.02)$ & 13 & $97.58(99.20)$ & 8 \\
\hline
\end{tabular}

Table 3 より提案手法の手法 4 は，動的にクラスタを 追加する場合にも手法 1 に比べて同等以上の認識率が得 られた。

血球データおよびサイロイドデータにはもともとは外 れ值が含まれていないと考えられているが，手法 4 で収 集したデー夕のうちでクラス境界から外れているデー夕 を外れ值として処理することにより認識率が上がってお り，これらのデー夕を外れ值とみることが妥当であるこ とを示している.

つぎに血球データとひらがなデータを選び，これらの 教師デー夕に外れ值を混入させ，四つの方法により比較
した結果を Figs. 2，3およびFigs. 4，5に示す.

まず，特徴量の一つを教師データごとにランダムに選 び，教師データの全体の０％から $10 \%(\mu \%)$ までこれま たランダムに選び，選ばれたデー夕に外れ值を混入させ る。ここで $0 \%$ は, 教師デー夕に外れ值が含まれないこ とを意味する。この教師デー夕により 4 通りの方法によ る学習を行い，それをテストデータで評価した結果を示 す．認識率は，外れ值を含ませる各\%ごとに乱数の初期 值を変えることにより 10 個の違った教師データにより学 習を行い，テストデータで評価した認識率の平均である.

Figs. 2, 3から 2 段階の手順を踏む手法 3 は外れ值を 含んだ教師データであっても手法 1 手法 2 に比べ最適に 学習できていることがわかる．Fig. 2の教師データの全 体の $2 \%$ 程度までに外れ值が含まれる場合, 手法 3 と外 れ值を考慮にいれていない従来手法はほぼ同じ認識率を 示している。これは，外れ值がごく少量含まれている場 合までは，外れ值が学習におよぼす影響は，従来手法の ファジィルールのチューニングによりカバーできている と思われる。

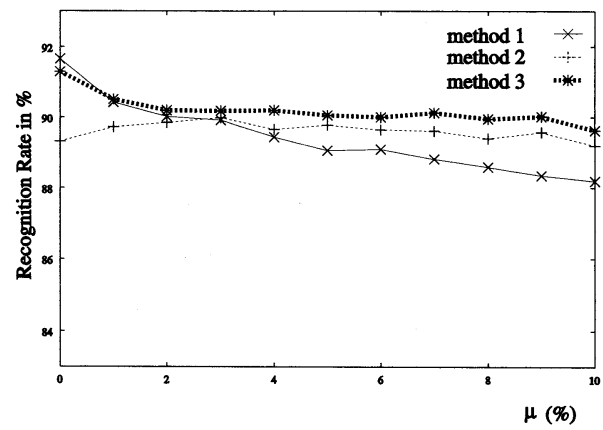

Fig. 2 Relation between $\mu$ and recognition rates for the blood cell data(Outliers are included in one of the training inputs.)

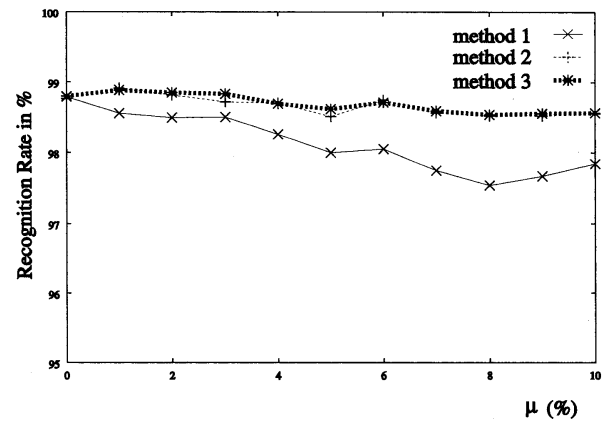

Fig. 3 Relation between $\mu$ and recognition rates for the hiragana data(Outliers are included in one of the training inputs.) 


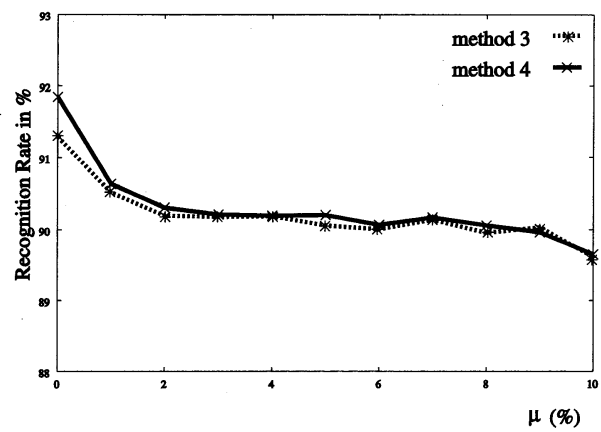

Fig. 4 Relation between $\mu$ and recognition rates for the blood cell data(Outliers are included in one of the training inputs.)

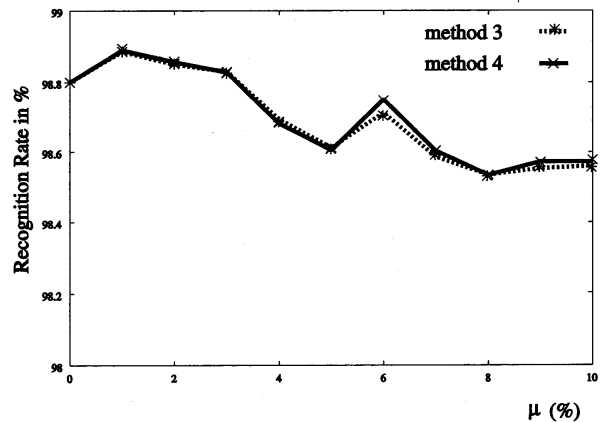

Fig. 5 Relation between $\mu$ and recognition rates for hiragana data(Outliers are included in one of the training inputs.)

Figs. 4, 5より提案手法である 2 段階の手順を踏み外 れ值を含むデータを考慮にいれてクラス間チューニング をした手法 4 は, 手法 3 よりさらに高い認識率を示すこ とがわかる. 血球デー夕に比べてひらがなデータの向上 が少ないのは従来のチューニングの方法により教師デー 夕の認識率が十分高いためである.

つぎに，それぞれ教師データの全体の０\%から $10 \%$ でランダムに各\%ごとに乱数の初期值を変え 10 回選び, その選ばれたデー夕の特徵量すべてに外れ值を混入させ 教師データとする。 4 通りの方法で学習を行い, テスト データにより評価した結果を示す. 認識率は, 同様に平 均認識率である。

同様にFigs. 6，7からクラスの境界を考慮にいれた 2 段階の手順を踏む手法 3 は従来手法の手法 1 よりも，ま た手法 1 に統計分野の 1 方法を適用した手法 2 よりも高 い認識率を示していることがわかる. Figs. 8,9より2 段階の手順を踏みクラス間チューニングをした提案手法 である手法 4 は手法 3 よりさらに高い認識率を示してい る。また教師デー夕に外れ值が多く含まれる場合に，よ り提案手法の効果が大きいこともわかる.

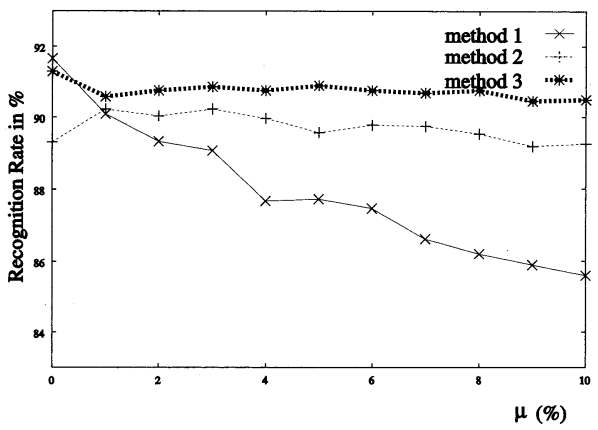

Fig. 6 Relation between $\mu$ and recognition rates for the blood cell data(Outliers are included in all of the training inputs.)

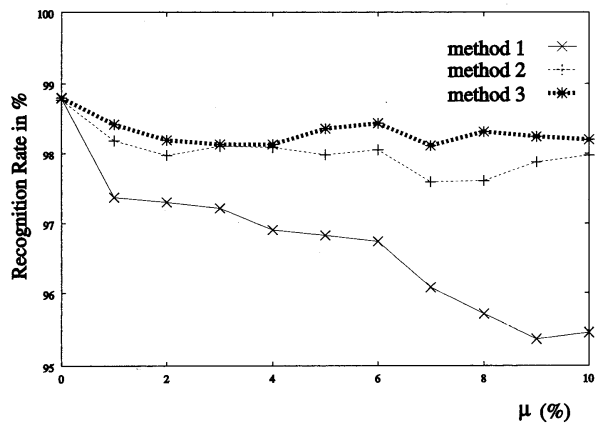

Fig. 7 Relation between $\mu$ and recognition rates for the hiragana data(Outliers are included in all of the training inputs.)

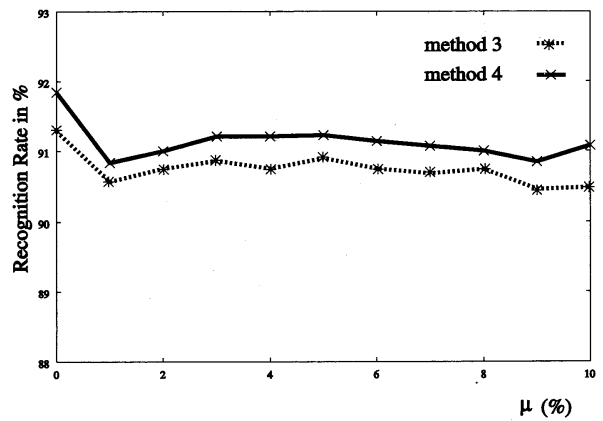

Fig. 8 Relation between $\mu$ and recognition rates for the blood cell data(Outliers are included in all of the training inputs.)

Tables 2，3，Fig. 2 から Fig. 9を通して，提案手法 である手法 4 は，外れ值を含んでいない場合にも既存の 手法と同程度かそれ以上の認識率が得られることがわか る。また外れ值を含んだような教師データにより学習を しなければならないような場合にも従来手法に比べ平均 して高い認識率を得られていることがわかる。これにより 提案手法である 2 段階の手順によりパラメー夕を求め新 


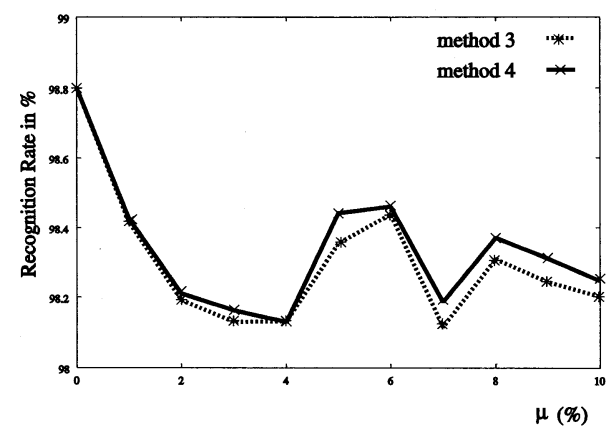

Fig. 9 Relation between $\mu$ and recognition rates for hiragana data (Outliers are included in all of the training inputs.)

たに外れ值を含むデータを考慮にいれたクラス間チュー ニングを行う学習方法は, 外れ值が混入しているデータ を含む教師データである場合また外れ值を含まない教師 データであっても最適に学習できるロバストなファジィ パターン認識法であるといえる.

\section{5. おわりに}

教師デー夕に外れ值を含む場合にロバストなパターン 認識を実現するために，本論文では楕円領域を持つファ ジィクラシファイアにおいて 2 段階の方法により領域近 似のパラメー夕を求め，ついで 2 クラス間チューニング をするロバストな学習法を提案した。つぎに提案手法を 数值計算で検討し, 提案手法は教師デー夕に外れ值が含 まれる場合において最適に学習できることを示した。ま た教師データに外れ值が含まれない場合にも従来法より も沉化能力の高いことを示した。この結果, 提案手法は 教師デー夕に外れ值が含まれる含まれないにかかわらず 汎化能力の高いロバストな学習法であることが示された.

\section{謝辞}

本研究を進めるにあたり，ご討論いただいた米森秀登助 手，血球デー夕を提供していたたいた川崎医科大学松田 信義教授, 数字およびひらがなデー夕を提供していただい た（株）日立製作所日立研究所小林芳樹技術主幹，および サイロイドデータ (ics.uci.edu: pub/machine-learningdatabases) を提供いただいたカリフォルニア大学アーバ イン校 P. M. Murphy 氏抢よび D. W. Aha 氏に感謝の 意を表する。

\section{参考文献}

[1] K. Liano: Robust error measure for supervised neural network learning with outliers; IEEE Trans. Neural Networks, Vol. 7, No. 1, pp. 246-250 (1996)
[2] D. S. Chen and R. C. Jain: A robust back propagation learning algorithm for function approximation; IEEE Trans. Neural Networks, Vol. 5, No. 3, pp. 467-479 (1994)

[3] S. Abe and R. Thawonmas: A fuzzy classifier with ellipsoidal regions; IEEE Trans. Fuzzy Systems, Vol. 5, No. 3, pp. 358-368 (1998)

[4] S. Abe: Dynamic cluster generation for a fuzzy classifier with ellipsoidal regions; IEEE Trans. Systems, Man, and Cybernetics-Part B, Vol. 28, No. 6, pp. 869-876 (1998)

[5] P. J. Rousseeuw and A. M. Leroy: Robust regression and outlier detection, pp. 256-265, John Wiley \& Sons, New York (1987)

[6] A. Hashizume, J. Motoike, and R. Yabe: Fully automated blood cell differential system and its application; Proc. IUPAC 3rd International Congress on Automation and New Technology in the Clinical Laboratory, pp. 297-302, Kobe, Japan (1988)

[7] S. M. Weiss and I. Kapouleas: An empirical comparison of pattern recognition, neural nets, and machine learning classification methods; Proc. IJCAI89, pp. 781-787 (1989)

[8] M. Takatoo, et al.: Gray scale image processing technology applied to vehicle license number recognition system; Proc. International Workshop on Industrial Applications of Machine Vision and Machine Intelligence, pp. 76-79 (1987)

[9] 武長, 阿部, 高藤, 鹿山, 北村, 奥山：感度解析を用いた ニューラルネットの入力層の最適化とその数字認識への適 用; 電気学会論文誌 D, Vol. 111-D, No. 1, pp. 36-44 (1991) 